\title{
Improving Constructing Explanations and Designing Solutions Skills based on NGSS through Project-Based Learning: A Systematic Review
}

\author{
Novia Rhike Dyah Pitaloka ${ }^{1}$, Suyanta $^{2}$, Khoirul Huda $^{3}$ \\ \{noviarhike.2019@student.uny.ac.id¹, suyanta@uny.ac.id², khoirulhuda.2019@student.uny.ac.id ${ }^{3}$ \} \\ Science Education Study Program, School of Postgraduate, Universitas Negeri Yogyakarta. \\ Jl. Colombo No.1, Yogyakarta 55281, Indonesia ${ }^{1}$, Department of Chemistry, Universitas \\ Negeri Yogyakarta. Jl. Colombo No.1, Yogyakarta 55281, Indonesia², Science Education \\ Study Program, School of Postgraduate, Universitas Negeri Yogyakarta. Jl. Colombo No.1, \\ Yogyakarta 55281, Indonesia ${ }^{3}$
}

\begin{abstract}
Constructing explanation and designing solution (CEDS) skills focus on skills in next generation science standards (NGSS) which describe science and engineering objectives that can be supported by project-based learning ( $\mathrm{PjBL})$. The purpose of this study to determine if the PjBL could improve CEDS skills. The research method used meta-synthesis approach and the data comes from the results of research that has been conducted and published in national and international online journals. The results of a systematic review explain that learning steps in PjBL can be implemented in learning to improve skills in a claim, evidence, reasoning, generate designing solutions, criteria-constraints, and evaluating potential solutions. PjBL provides opportunities for students to access various forms of information needed and demonstrate it in different ways; actively involved in learning by making choices and decisions that show independent learners, and reflect on learning and make revisions based on self-assessment and feedback from the teacher.
\end{abstract}

Keyword: NGSS, constructing explanations and designing solutions, project-based learning

\section{Introduction}

The development of science and technology marks the 21st Century is overgrowing, emphasizing the combination of technology and human qualities. Requires human resources who can take the initiative, think critically, creatively, skilled in problem-solving, also to changes in the education system that is more comprehensive and flexible. Quality education certainly involves students to learn actively and make changes to better conditions. Science education, which is the main focus, plays a role in preparing students to understand the nature of science, think critically, and have the skills to meet the challenges of the 21st Century [1] [2]. 
The low level of human resources in Indonesia shows the low quality of education as a producer of skilled and quality generations. The results of the Program for International Student Assessment (PISA) in 2018 the ability of Indonesian students, especially in the field of science, got a score of 396 from the international standard score of 489 [3]. Indonesia is at level 1, meaning that students can identify information and solve problems according to explicit instructions and have not been able to carry out procedures properly, including methods that require sequential decisions [3]. Causes the emergence of problems in science process skills that affect student's creative thinking abilities. To be able to develop and improve student science skills, a teacher must carry out various innovations and reforms in education. Such as adopting education standards from a superior country, namely the Next Generation Science Standard (NGSS). Related to how can put science into practice, NGSS facilitates students through the integration and implementation of three NGSS dimensions, namely the dimensions of Science and Engineering Practice (SEPs), Disciplinary Core Ideas (DCIs), and Crosscutting Concepts (CCs) [1] [4].

One of the objectives of NGSS is to optimize student practice skills by constructing explanations and designing solutions (CEDS). CEDS is a skill in explaining phenomena based on evidence from research and designing solutions to formulate conclusions [5]. Skills that focus on explanation as a manifestation of the nature of knowledge in constructing explanations related to phenomena through an investigation [6]. Meanwhile, the gift of designing problem solutions plays a role so that students can do research, innovate, and solve problems [2].

PjBL can support the application of CEDS in learning by selecting an appropriate learning model, namely Project-based learning (PjBL). A learning model that allows students to develop creativity in designing and doing projects that use to solve problems [7]. PjBL will enable students to become interactive learners and build knowledge through exploration that allows students to demonstrate organized learning outcomes to increase their knowledge and progress in learning [8]. This is consistent with the application of PjBL in science learning which is known to improve cognitive learning outcomes and science process skills [9] [10].

PjBL supports the process of finding truth through a process of inquiry to answer questions about natural phenomena and engineering that are more focused on solving problems through a series of design processes, so that students can increase understanding with the knowledge found [11]. Integrating design activities in the NGSS carried out in the PjBL learning model can enable students to be involved in defining problems and designing solutions [12]. Based on the description above, it can be a significant finding when researchers can implement NGSS standards in projectbased learning to improve CEDS. So, the research problem arises how can the results of a review project-based learning model can be enhanced CEDS skills?

\section{Method}

This research is a systematic review that is used to collect data or sources related to a particular topic through journals, books, the internet, and other literature. This type of research used in the review literature focuses on research results related to the topic or variable of writing, using the meta-synthesis method with a meta-ethnographic approach which aims to develop new theories to complement existing theories. The outcome measured in this study was a project-based learning model in improving CEDS skills. This research used the meta-synthesis method consisting of 6 steps which were adopted from Francis \& Baldesari (2006). These steps are: (1) Formulating research 
questions (2) Conducting systematic review literature searches (3) Screening and completing suitable research articles (4) Conducting analysis and synthesis of qualitative findings (5) Implementing quality control (6) Developing final report [13].

The first stage is to formulate questions on the research topic, how can the results of a review project-based learning model improve CEDS skills? The second stage is to conduct a systematic review literature search, the data used in this study come from the results of research that have been conducted and published in national and international online journals. In this study, researchers searched journals published on the internet using the Google Scholar search engine, the Education Resources Information Center (ERIC), and Taylor and Francis. The third stage, screening and selecting articles begins with determining the keywords to be used. These keywords are next generation science standards, constructing explanation - designing solution, and project-based learning. The process of collecting data by filtering based on criteria determined by the author of each journal taken. The criteria for journal collection are the years of literature sources taken from 2010 to 2020, the suitability of writing keywords, interest in writing results, and discussion and strategies for collecting various literature using an accredited journal site.

The fourth and fifth stages, namely analyzing and synthesizing findings and enforcing quality control, are carried out when selected articles have gone through the screening stage which is then analyzed by experts in the field of articles related to quality, data accuracy, and quality-focused research questions. The sixth stage is compiling the final report which is done by writing the results of the review. This literature review is synthesized using a narrative method by classifying similar extracted data according to the measured results to answer the research problem. The results of the extraction of the journal are then analyzed for the content contained in the research objectives and the results/research findings. The analysis used to analyze the contents of the journal was carried out using coding. The data that has been collected is then searched for similarities and differences and then discussed to conclude. The remainder of the article is organized as follows: part 3 as a result and discussion presents a review of project-based learning which is can improve constructing explanation and designing solution skills based on NGSS. Section 4 concludes from the articles that have been prepared.

This research begins by searching for journal articles through three online search engines source; there are Google Scholar, Taylor \& Francis, and the Education Resources Information Center (ERIC) in Table 1.

Table 1. List of Articles Found

\begin{tabular}{lccc}
\hline \multirow{2}{*}{ Key Word } & \multicolumn{3}{c}{ List of Articles Found } \\
\cline { 2 - 4 } & 1.050 .000 & Taylor \& Francis & ERIC \\
\hline Constructing explanation & 4.280 .000 & 612 & 247 \\
Designing solution & 5.110 .000 & 493 & 193 \\
Project-based learning & 611 & 18.780 \\
\hline
\end{tabular}

Based on three online search engines source, it found that Google scholar has a much higher number than Taylor \& Francis and ERIC (Table 1). However, if we look at the quality of the articles, Tailor \& Francis and ERIC are higher than Google Scholar. Based on the papers have gone through the screening stage, the next step is to answer the research problem that have to ask. However, improving constructing explanations and designing solutions skills based on NGSS through projectbased learning has never been done, so it will be a very big opportunity for further researchers to continue research by this topic. 


\section{Result and Discussion}

\subsection{Constructing Explanation and Designing Solution Skill}

CEDS skills are one of the skills in the scientific and engineering practice dimension that describes the achievement of the main goals of science and engineering [4]. Students involve themselves in various practical activities that will understand that science and engineering are a process to develop an explanation and formulate solutions to every problem [14]. NGSS Lead State (2013) describes CEDS skills into one unit with the indicators shown in Table 2.

Table 2. Indicators of Constructing Explanation and Designing Solution Skills

\begin{tabular}{|c|c|}
\hline Aspect & Indicator \\
\hline $\begin{array}{l}\text { Constructing } \\
\text { Explanation }\end{array}$ & $\begin{array}{l}\text { 1. Compiling a scientific explanation based on facts obtained from various } \\
\text { sources and assumptions that a theory and law that explains the mechanism of } \\
\text { nature in the past, present, and } \\
\text { 2. Apply ideas, principles, and facts to construct and improve by using scientific } \\
\text { explanations to explain natural phenomena }\end{array}$ \\
\hline Designing Solution & $\begin{array}{l}\text { 3. Apply science reasoning to show why can use data to conclude. } \\
\text { 4. Apply ideas to design and test an object design. } \\
\text { 5. Designing a project by applying design steps to formulate a solution by the } \\
\text { criteria. } \\
\text { 6. Optimizing the way the design works }\end{array}$ \\
\hline
\end{tabular}

The development of constructing explanation skills provides an understanding of scientific concepts that will affect students in formulating a scientific explanation. The constructing explanation activity focuses on scientific explanations to describe the reasons for preparing a logical scientific explanation related to the observed phenomena [15]. The scientific explanation is organized into three main points. More detail in Table 3.

Table 3. Aspects of Scientific Explanation

\begin{tabular}{ll}
\hline \multicolumn{1}{c}{ Aspect } & \multicolumn{1}{c}{ Description } \\
\hline Claim & $\begin{array}{l}\text { A statement that answers a question. Claims consider right when they can answer questions } \\
\text { that are supported by sufficient evidence and logical reasoning. }\end{array}$ \\
Evidence & $\begin{array}{l}\text { Evidence of scientific data to support the claim. Evidence that is meant to come from } \\
\text { observations or based on existing data, and is used to support the formulated scientific } \\
\text { explanation }\end{array}$ \\
& $\begin{array}{l}\text { A reason for linking data as evidence supporting a statement using proper scientific } \\
\text { principles based on scientific knowledge, theories, and models. }\end{array}$ \\
\hline
\end{tabular}

The use of a claim, evidence, and reasoning (CER) framework in learning can support CEDS skills, which will have an impact on students regarding their understanding of a scientific explanation and students are able to compile a scientific explanation [16]. If the teacher applies the CER framework in learning, students will get a firm understanding in compiling scientific explanation based on their knowledge [16]. Based on the CER framework described above [19], the constructing explanation aspect becomes more operational. More details in Table 4

Table 4. Aspects of Constructing Explanation 


\begin{tabular}{ll}
\hline \multicolumn{1}{c}{ Aspect } & \multicolumn{1}{c}{ Description } \\
\hline $\begin{array}{l}\text { Emphasizes the explanation of a } \\
\text { phenomenon }\end{array}$ & $\begin{array}{l}\text { Emphasizes the explanation of a phenomenon that includes the level } \\
\text { of understanding a mechanism }\end{array}$ \\
Evidence & $\begin{array}{l}\text { Provide evidence to support the scientific explanation. The evidence } \\
\text { comes from existing data and is used to support the scientific } \\
\text { explanation formulated. } \\
\text { Be able to explain the reasons that link evidence to phenomena based } \\
\text { on concepts obtained from theories or models. }\end{array}$ \\
\hline
\end{tabular}

In a science and engineering process, the NGSS standard has been integrated simultaneously as an example of constructing explanation, in this case, it is necessary to have skills in designing solutions as a compliment because these two skills are related and complementary [17]. The NGSS framework describes solution designing skills to enhance design-related ideas, test a model, and determine the criteria and limits for the desired quality of the solution [4]. Furthermore, SDCOE (2017) describes several aspects and indicators of designing solution skills, more detail in Table 5.

Tabel 5. The aspect of Designing Solution

\begin{tabular}{cl}
\hline Aspect & \multicolumn{1}{c}{ Indicator } \\
\hline Designing Solution & Generate design solution \\
& Describe criteria and constraints \\
& Evaluating potential solutions \\
& Optimizing solutions \\
\hline
\end{tabular}

Based on several descriptions of CEDS skills that have described, there are six aspects with each indicator. More detail in Table 6.

Tabel 6. Aspect and Indicator Constructing Explanation and Designing Solution

\begin{tabular}{|c|c|}
\hline Aspect & Indicator \\
\hline Claim & 1. Emphasizes the explanation of a phenomenon \\
\hline Evidence & 2. Presenting valid and reliable evidence to support a scientific explanation \\
\hline Reasoning & $\begin{array}{l}\text { 3. Explain the reasons that link evidence to phenomena, based on scientific } \\
\text { knowledge, theories, and models }\end{array}$ \\
\hline $\begin{array}{l}\text { Generate } \\
\text { solution }\end{array}$ & 4. Applying a scientific idea or principle to design a solution to a problem \\
\hline Criteria and constraint & $\begin{array}{l}\text { 5. Describe the criteria and obstacles that may be faced in the selection of a } \\
\text { problem }\end{array}$ \\
\hline $\begin{array}{l}\text { Evaluating } \\
\text { solution }\end{array}$ & 6. Evaluating various solutions and selecting the optimal solution. \\
\hline
\end{tabular}

\subsection{Project-based Learning ( $\mathrm{PjBL})$}

Project-based learning is a form of student-centered learning based on three constructivist principles: specific and authentic learning, learning that allows students to be actively involved in the learning process, and learning to achieve learning goals through social interaction with various knowledge and understandings [20 ]. It is known that the challenges experienced by students that arise in designing affect the high level of student involvement [21]. PjBL is consider as a type of 
inquiry-based learning, where the context of education is provided through questions that lead to meaningful learning experiences [22].

The characteristics of $\mathrm{PjBL}$ focus on problem-solving and provide opportunities to work independently in building knowledge to produce products [24]. Based on this explanation, it can say that PjBL helps students learn independently and can convey the students' conceptual understanding systematically at certain levels [25]. PjBL explores in different phases of education, from earlystage to school to higher education. Learning steps using a project-based learning model based on The George Lucas Educational Foundation (2005) in Table 7 as follow.

Table 7. Project-Based Learning Steps

\begin{tabular}{|c|c|c|}
\hline & Steps of $\mathrm{PjBL}$ & Description \\
\hline 1) & $\begin{array}{l}\text { Start with the big } \\
\text { question }\end{array}$ & Learning begins with questions that encourage students to carry out an activity. \\
\hline 2) & $\begin{array}{l}\text { Design a plan for the } \\
\text { project }\end{array}$ & $\begin{array}{l}\text { Planning is done based on discussions from students and teachers. It means that } \\
\text { students feel responsible for the project. Planning contains the selection of } \\
\text { projects, time to complete, and the tools and materials required. }\end{array}$ \\
\hline 3) & Create a schedule & $\begin{array}{l}\text { Students and teachers should arrange a schedule of activities in completing the } \\
\text { project. The scheduling must be precise because the completion of a project } \\
\text { takes a long time. The teacher keeps reminding when student activities deviate } \\
\text { from the project objectives. }\end{array}$ \\
\hline 4) & $\begin{array}{l}\text { Monitor the progress } \\
\text { of the project }\end{array}$ & $\begin{array}{l}\text { The teacher is responsible for monitoring student activities by facilitating } \\
\text { students in each process. }\end{array}$ \\
\hline 5) & Assess the outcome & $\begin{array}{l}\text { Assessment carries out to help teachers measure the achievement of standards } \\
\text { and provide feedback about the level of understanding that has been achieved } \\
\text { by students. Product assessment carries when the group presents the final } \\
\text { product. }\end{array}$ \\
\hline 6) & $\begin{array}{l}\text { Evaluate the } \\
\text { experience }\end{array}$ & $\begin{array}{l}\text { Teachers and students reflect on the activities and project results that harry } \\
\text { work. Students ask to share their experiences while completing the project }\end{array}$ \\
\hline
\end{tabular}

There are four strategies in implementing PjBL in schools, there are 1) doing it in two ways; 2) recognize previous efforts; 3) make use of the word "and", 4) make the class an open place [27]. One way to avoid failure in implementing PjBL is that a problem solution is needed. Teachers can avoid common mistakes by following seven procedures adapted from Hung (2008) as follows: 1) determining the suitability of the material with PjBL; 2) analyzing the material; 3) write down possible problems; 4) describe potential solutions; 5) calibrate the project; 6) illustrates the task; and 7) reflect on learning [28].

\subsection{Improving Constructing Explanations and Designing Solution Skill Through a Project-Based Learning}

NGSS supports learning through the application of science and engineering practices based on project-based learning, performance-based assessments, and structured group work. Besides providing opportunities for students to solve real problems scientifically. For each activity unit creating a project allows students to 1) access various forms of information required;2) actively 
involved in learning that shows the results of independent learning, and 3) reflect on learning by making revisions based on peer and teacher assessments [29].

As we discussed above, the indicators for CEDS skills are claim, evidence, reasoning, generate a designing solution, criteria - constraints, and evaluating potential solutions. These indicators can be achieve using project-based learning methods. Project-based learning focuses on creative thinking, problem-solving, and student interaction to create and use new knowledge. For more details, the relationship between CEDS in NGSS and PjBL explain in Figure 1, as follows.

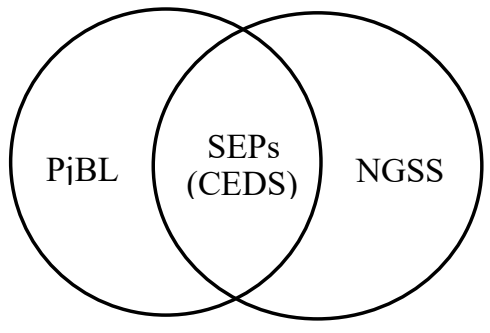

Fig 1. Dependence CEDS Based on NGSS and PjBL

The use of the PjBL model in learning that is in line with the NGSS as a way to strengthen science teaching for students. Apply project-based learning to be a very effective way to meet the demands of new standards. Also, it combines performance appraisal and effective work strategies to increase student involvement in the learning process. Thus, it can see the method required for implementing PjBL in improving practice required CEDS skills in Table 8.

Table 8. Description Box of the PjBL in Enhancing CEDS Skills

\begin{tabular}{|c|c|c|}
\hline Steps of $\mathrm{PjBl}$ & Indicator CEDS & Description \\
\hline Essential question & - & $\begin{array}{l}\text { Provide questions that will lead students to the } \\
\text { context of project-based learning and assign } \\
\text { assignments to students to carry out controlled } \\
\text { activities. }\end{array}$ \\
\hline $\begin{array}{l}\text { Design plan for a } \\
\text { project }\end{array}$ & - & $\begin{array}{l}\text { Prepare a project plan that will w. Activities that will } \\
\text { be carried out include: 1) determining tools and } \\
\text { materials; 2) determine the rules of the game; 3) } \\
\text { selection of activities to be carried out as answers to } \\
\text { essential questions; 4) determine the implementation } \\
\text { of the project with their respective duties and } \\
\text { responsibilities. }\end{array}$ \\
\hline Create a schedule & - & $\begin{array}{l}\text { Make a schedule of activities to be carried out based } \\
\text { on the actions to carry out by the plan. }\end{array}$ \\
\hline $\begin{array}{l}\text { Monitor and } \\
\text { project progress }\end{array}$ & - & $\begin{array}{l}\text { Performed as work control which is guidance from } \\
\text { educators so that students carry out their activity } \\
\text { correctly. }\end{array}$ \\
\hline
\end{tabular}




\begin{tabular}{|c|c|c|}
\hline $\begin{array}{l}\text { Assess the } \\
\text { outcome }\end{array}$ & & $\begin{array}{l}\text { Assessment is carried out on student work to } \\
\text { measure student competency achievement. }\end{array}$ \\
\hline & Constructing an explanation & \\
\hline & - Claim & Emphasize the explanation of a phenomenon \\
\hline & Evidence & $\begin{array}{l}\text { Presenting valid and reliable evidence to support a } \\
\text { scientific explanation }\end{array}$ \\
\hline & Reasoning & $\begin{array}{l}\text { Explain the reasons that link evidence to phenomena, } \\
\text { based on scientific knowledge, theories, or models }\end{array}$ \\
\hline & Designing & \\
\hline & $\begin{array}{l}\text { - Generate designing } \\
\text { solution }\end{array}$ & $\begin{array}{l}\text { Apply a scientific idea or principle to design a } \\
\text { solution to a problem }\end{array}$ \\
\hline & - Criteria and constraint & $\begin{array}{l}\text { Describe the criteria and obstacles that may be in the } \\
\text { selection of a problem }\end{array}$ \\
\hline & $\begin{array}{l}\text { Evaluating potential } \\
\text { solution }\end{array}$ & $\begin{array}{l}\text { Evaluating various solutions and selecting the } \\
\text { optimal solution. }\end{array}$ \\
\hline Project evaluation & - & Reflect on project implementation. \\
\hline
\end{tabular}

The use of PjBL in improving CEDS skills see from the advantages of implementing PjBL, such as enhancing student skills in managing research. In finding solutions to project assignments, students can construct knowledge of various sources [30]. Meet the needs of students with different learning skill levels and techniques. One of the exciting things, why PjBL is essential to implement, is shown by several studies that show that students can implement PjBL with confidence and optimism that it can improve students' science process skills and creative thinking [31]. Also, found that $86 \%$ of the implementation PjBL was more effective than the application of traditional teaching approaches [10]. PjBL also has a significant effect on creative thinking skills and science process skills [32]. Can connect PjBL with NGSS in increasing students' appreciation of the importance of science in life, involving students in science practice and increasing student confidence in communicating scientific topics [33]. NGSS and PjBL prove to be attractive aspects for students in the world of education, this is by the statement [34] that through the NGSS platform students can become more motivated and inspired in the formal education system. This motivation and inspiration increase students ability to learn and increases their will to persist in their educational quest.

\section{Conclusion}

Based on the results of the systematic review which shows that CEDS skills can be improved, one of which is the application of PjBL in learning as evidenced by theory and several previous studies which are linked based on the results of the synthesis. To improve CEDS skills, educators can apply learning steps based on PjBL to meet skill achievements in CEDS, in the form of claims, evidence, reasoning, generate designing solutions, criteria - constraints, and evaluating potential solutions. PjBL also provides student learning experiences because students construct concepts from the projects they are working on. 


\section{References}

[1] Next Generation Science Standards. 2013. Next Generation Science Standards: For States, By States. Volume 1: The Standards-Arranged by Disciplinary Core Ideas and by Topics. (Washington, DC: The National Academies Press).

[2] OECD. 2017. PISA for Development Assessment and Analytical Framework Reading, Mathematics, and Science. (Paris: OECD).

[3] OECD. 2018. PISA 2018 Result What Students Know and Can Do: Volume I. Paris: OECD.

[4] National Research Council (NRC). 2012. Education for Life and Work: Developing Transferable Knowledge and Skills in the 21st Century. (Washington, DC: The National Academies Press).

[5] NGSS Release Appendix F.2013. Science and Engineering Practices in the NGSS.

[6] Chiappetta E L \& dan Koballa T R. 2010. Science Instruction in The Middle and Secondary Schools: Developing Fundamental Knowledge and Skills. (United States Of America: Pearson Education Inc).

[7] Abdullah S.R . 2014. Pembelajaran saintifik untuk kurikulum 2013. (Jakarta: Bumi Aksara).

[8] Lattimer H \& Riordan R. 2011. Project-Based Learning Engages Students in Meaningful Work. Middle School Journal, 43(2), 18-23. DOI: http://dx.doi.org/10.1080/00940771.2011.11461797

[9] Filippota D \& Kaldi S. 2010. The Effectiveness of Project-Based Learning on Pupils with Learning Difficulties Regarding Academic Performance, Group Work And Motivation. International Journal of Special Education. 25 (1), 17-26. Retrieved from https://files.eric.ed.gov/fulltext/EJ890562.pdf

[10] Balemen N \& Özer K M. 2018. The effectiveness of Project-Based Learning on science education: A meta-analysis search. International Online Journal of Education and Teaching (IOJET), 5(4), 849-865. http://iojet.org/index.php/IOJET/article/view/452/297

[11] Zajkov O \& Mitrevski, B. 2012. Project-Based Learning: Dilemmas And Questions!. Macedonian Physics Teacher, 48, 1- 11.

[12] Engels M, Miller B, Squire A, Jennewein J, \& Eitel K. 2017. The Confluence Approach: Developing scientific literacy through project-based learning and place-based education in the context of NGSS. Electronic Journal of Science Education. 23(3), 33-58. Retrieved from https://files.eric.ed.gov/fulltext/EJ1228452.pdf

[13] Francis C \& Baldesari. 2006. Systematic Reviews of Qualitative Literature. (Oxford: UK Cochrane Centre).

[14] National Science Teacher Associations (NSTA). 2011. Quality Science Education and $21^{\text {st }}$ Century Skills. Retrieved from: https://www.nsta.org/nstas-official-positions/quality-science-education-and21st-century-skills

[15] Krajcik J, Codere D, \& Dahsah C. 2011. Project-Based Learning Engage Student in Meaningful Work: Student at High Teach Middle Engage in Project-Based Learning. Middle School Journal. 42(2), 1832.

[16] McNeill K L \& Krajcik J. 2007. Scientific explanations: Characterizing and evaluating the effects of teachers' instructional practices on student learning. Journal of Research in Science Teaching, 45(1), 53-78. doi:10.1002/tea.20201.

[17] Metz S., 2016. Constructing Explanations and Designing Solution. Academic Journal Article: The Science $\quad$ Teacher. $83(1), 6$ Retrieved from https://search.proquest.com/docview/17555024789?accountid=31324

[18] National Research Council (NRC). 2012. Education for Life and Work: Developing Transferable Knowledge and Skills in the 21st Century. (Washington, DC: The National Academies Press).

[19] SDCOE (San Diego Country Office of Education). 2017. Plan Tool for Contructing ExplanationDesigning Solution. (San Diego: Resource Developed by C.Coch Rane and J.Spiegel). Retrieved from https://ngss.sdcoe.net. 
[20] Kokotsaki D, Menzies V, \& Wiggins A. 2016. Project-Based Learning: A Review of The Literature. Improving Schools, 19(3), 267-277. DOI:10.1177/1365480216659733.

[21] Karaçalli S \& Korur F. 2014. The Effects of Project-Based Learning on Students' Academic Achievement, Attitude, and Retention of Knowledge: The Subject of "Electricity in Our Lives." School Science and Mathematics, 114(5), 224-235. DOI : https://doi.org/10.1111/ssm.12071

[22] Kaldi S, Filippatou D, \& Govaris C. 2011. Project-based learning in primary schools: effects on pupils' learning and attitudes. Education. 39(1), 35-47. DOI: 10.1080/03004270903179538.

[23] Kemendikbud. 2013. Peraturan Menteri Pendidikan dan Kebudayaan, Nomor 81A, Tahun 2013, tentang Implementasi Kurikulum Pedoman Umum Pembelajaran.

[24] Thomas J W. 2000. A Review of Research on Project Based Learning. (California: The Autodesk Foundation).

[25] Fernandes S, Mesquita D, Flores M A, \& Lima R M. 2013. Engaging Students in Learning: Findings from a Study of Project-Led Education. European Journal of Engineering Education, 39(1), 55-67. DOI: $10.1080 / 03043797.2013 .833170$

[26] The George Lucas Educational Foundation. 2005. Instructional Module, Project-Based Learning. Retrieved from: http://www.edutopia.org/modules/PBL/whatpbl.php

[27] Aldabbus S., 2018. Project-Based Learning: Implementation \& Challenges. International Journal of Education, Learning and Development. 6(3). 71-79. Retrieved from http://www.eajournals.org/

[28] Vega V., 2012. Project-based learning research review. Diakses 24 November 2020. Retrieved from: http://edutopia.org/pblresearch-learning-outcomes

[29] Holthuis N, Deutscher R, Suson E, \& Jashidi A. 2018. The New NGSS Classroom: A Curriculum Framework for Project-Based Science Learning. Retrieved from: https://files.eric.ed.gov/fulltext/EJ1182064.pdf

[30] Kizkapan O \& Bektaş O. 2017. The Effect of Project Based Learning on Seventh Grade Students' Academic Achievement. International Journal of Instruction. 10(1). 38-54. Retrieved from http://www.e-iji.net/dosyalar/iji_2017_1_3.pdf

[31] Anazifa R D \& Djukri. 2017. Project- Based Learning And Problem- Based Learning: Are They Effective To Improve Student's Thinking Skills?. Jurnal Pendidikan IPA Indonesia. 6(2). 346-355. DOI: 10.15294/jpii.v6i2.11100.

[32] Angga R U C, Nur K, \& Harto N. 2016. Efektivitas Model Project Based Learning terhadap Keterampilan Proses Sains dan Kemampuan Berpikir Kreatif Siswa pada Pokok Bahasan Kalor Kelas X SMAN 1 Wonosegoro Tahun Pelajaran 2014/2015. Jurnal Penelitian Pembelajaran Fisika. 7, 1924. Retrieved from http://e-jurnal.upgrismg.ac.id/index.php/JP2F

[33] Mary A, Brant M, Audrey S, Jyoti S J, dan Karla E. 2017. The Confluence Approach: Developing Scientific Literacy Through Project-Based Learning and Place-Based Education in The Context Of NGSS. Electronic Journal of Science Education. 23(3). 33-58. Retrieved from http://ejse.southwestern.edu 